Obituary

\title{
In memoriam: Dan Hardy Yaalon 1924-2014
}

The Editors of Catena mourn the loss of our colleague Dan Yaalon.

Below are two remembrances from colleagues on Dan's contributions to pedology and history of soil science.

Dan H. Yaalon was one of the most influential soil scientists in many decades, a long-standing faculty member of the Institute of Earth Sciences of the Hebrew University of Jerusalem, a much decorated scientist with colleagues from many disciplines, and a devoted family man. Dan passed away on Wednesday 29 January 2014. He was 89.

Dan touched the ideas, the research, and students of many scientists. He traveled widely as a way to encourage soil science, to accelerate his own soils education, and to represent soil science to the world. I never met Dan, but I corresponded with him electronically over many years, as did many. Recently, we co-wrote two papers, and throughout the writing he worried that he was not up on the literature and thus not a strong co-author. His contributions as co-author were classic Yaalon intense, critical, and creative.

Dan's soil scholarship is remarkable for both its fundamental nature and its breadth. He is one of only three winners of the V.V. Dokuchaev Prize given by the International Union of Soil Sciences. By the end of his career, he had made signature contributions to:

- deserts and desert soils - for demonstrating how soils in xeric environments are formed by dynamic pedogenetic processes, and especially from wind deposited loess

- paleo-pedology - for conceptualizing how past records of climates, biota, and geomorphologies are contained within paleosols, i.e., fossilized and buried soils

- anthro-pedology - for articulating how naturally formed soils are becoming the parent material for human-formed soils

- pedology - for how Earth's soils are often poly-genetic, i.e., palimpsests with paleosolic features

- soil science history, philosophy and sociology - for establishing a whole, new sub-discipline of soil science

While all five are important, two of these, polygenesis and anthropedology, are some of the most significant developments in the history of soil science itself.

This In Memoriam will not detail specifics of Yaalon's research, they are widely accessible in the literature, but rather I write about the making of Dan Yaalon the scientist. I use this opportunity to describe how his life offers much to young scientists as they consider a life's work with the Earth's soil.

Born in Czechoslovakia in 1924, Yaalon lost his mother in Auschwitz-Birkenau, a mother who had put him on a train at age 15 bound for Denmark to save him from the Nazis. At the time his name was Hardy Berger and his idea was to travel through Denmark and Scandinavia on his way to Mandate Palestine.
After arriving in Denmark, Hardy was assigned manual farm labor, but he took up his interrupted studies at an agricultural high school and later formally enrolled at the Agricultural University in Copenhagen. When the Nazis occupied Denmark, the Danish underground moved him and many other Jews to Sweden, where he found a job at the Agricultural University in Uppsala. Quite by accident, he was assigned to the research laboratory of Sante Mattson, a great soil chemist.

Yaalon later recalled, "Working with Mattson ... at research tasks far beyond my acquired learning, I delved into advanced publications and books, working my way backwards from difficult expressions, formulas or citations, to the basics which explained what I was doing ... This was a kind of backtracking detective work that branded my later activities in basic soil science." The experience with Mattson was life altering as it firmly turned Yaalon to the science of Earth's soil.

Late in the war and shortly thereafter, he traveled to Britain with the Czech Army and to Czechoslovakia where viewing post-war desolation he wrote with grave understatement, "visits to my hometown ... were not very uplifting." By July 1948, he had completed his undergraduate B.Sc. degree, worked as an assistant in a Danish research laboratory, and finally traveled by ship for Haifa to enter the new nation of Israel then two months old.

During a year in the Israel army, he visited agricultural settlements, mixed with scientists, joined geological expeditions into the Negev, and was accepted at the Hebrew University of Jerusalem for PhD studies. During these years he hebraized his name to "Dan Yaalon", something that signaled an established life in Israel, and married Rita Singer. Together Rita and Dan shared nearly six decades and established a family that includes two sons and daughters-in-law, and seven grandchildren.

As a PhD student in the early 1950s, the soil chemist Avraham Adolf Reifenberg became Yaalon's advisor. Yaalon was impressed by the small Department of Soil Science's focus on arid zone soils, common worldwide but vastly understudied at that time with significant questions and needs that ranged from the local to global. In day-to-day terms however, Yaalon commented, "Doing research in those early days, with meager resources, involved overcoming many difficulties. Essentially self-taught we did our best to establish the research and teaching laboratories."

These comments reveal perspectives strongly held by Yaalon about life and work. To Yaalon, "ingrained curiosity" was the basis for successful engagement with science. Yaalon's university education, in Denmark, Sweden, and Israel, challenged him in ways that fed his native curiosity and gave him confidence that Earth's soil was well worth a life's work. The making of a scientist according to Yaalon, included much that is fortuitous, unplanned, and even unfair, but what makes a successful scientist is "grabbing an opportunity when it arises." Whether in science or in life, he said, "much is due to accidental events but what you make of it is very much subject to your choice and efforts." Given the gravity of the "accidental events" in Yaalon's life, these words underscore an incredibly positive message about science, life, and living. 
"Soil Science has no age but will always be remembered through its history."

These words were used in 2000 at the Ghent University to honor Dan Yaalon's contributions to the history of soil science (Gabriels 2000).

Dan was born in 1924 in a small town in the former Czechoslovakia. His original name was Hardy Berger but he changed it shortly after coming to Israel. "Yaalon" was a play on the German meaning of Berger (a mountain dweller), his mother's Czech surname Jellinek (a mountain goat) and the Hebrew word "Aliyah" (literally, ascent), which united the three concepts. Now it is our time to say good-bye to Dan and to honor his achievements. Dan was not the first to study the history of soil science, but he contributed richly and uniquely to its growing archive of scholarship, and was the moving force in creating a community in which it could prosper. And Dan saw history as but one component of the study of soils in the context of the human experience. While the philosophy and sociology of soil science remain in the incipient stage, Dan's vision made a place for them at the table and he actively encouraged other scientists to take up study of these topics.

Dan recognized that providing an institutional home and framework for such non-traditional studies could enhance the scattered activities of isolated investigators and attract new workers. Dan took that first step by initiating the founding of a Working Group on the History, Philosophy and Sociology of Soil Science within the International Society of Soil Science (ISSS) in 1982 (IUSS, 1982). The new committee spun off a Council in the Soil Science Society of America (SSSA) in 1990 (Brevik, 2011), and both groups began active programs of symposia and publications that continue to this day. Within the ISSS, symposia were organized and chaired by Dan at the World Congresses in 1990 (Kyoto; Historical, philosophical and sociological aspects of development in soil science), 1994 (Acapulco; Origin and transmission of ideas in soil science), and 1998 (Montpellier; Attitudes to soil care and land use through human history). Dan was also a central figure in organizing a symposium at the 2006 WCSS (Philadelphia; History of Soil Science in Developing Countries). Even though his health did not allow him to travel to the Congress and a co-organizer served as chair, Dan helped lead the symposium through the proposal stage and secured many commitments for presentations.

Dan edited the landmark volume History of Soil Science (Yaalon and Berkowicz 1997) and he was a key player in the conceptualization of Footprints in the Soil (Warkentin 2006). The former volume took some six years of work and at a time when one was still reliant on regular postal mail. The IUSS Committee on the History, Philosophy, and Sociology of Soil Science has also been active in producing newsletters since its founding, with 20 newsletters produced on a schedule that has alternated from annual to something less than that.. For part of its run, Dan served as the editor and after those duties were completed he continued to take an active interest in the newsletters and was very helpful in finding contributors to it. In 2010 Dan received the Doukouchaev medal for his overall achievements in soil science.

In Dan's autobiography published in 2012 ("The Yaalon Story") he provided us with a fitting epitaph: "I am overwhelmed by the fact that starting from a small town in Czechoslovakia, surviving that fateful and devastating Holocaust, I have succeeded in making a contribution for the benefit of mankind - which I consider as an acceptable criterion for evaluating my work." Dan published extensively with a focus on the soils and geomorphology of arid regions, the effects of land use changes on soils, and paleosols. Quite recently, he collaborated on an important philosophical paper (Richter and Yaalon, 2012) that proposed a new model of soil which posited the emerging science of anthropedology. While a complete list of his publications is given in Yaalon (2012), the following is a list of his works in the history of soil science:

Yaalon, D.H. 1989. The earliest soil maps and their logic. Bulletin of the International Society of Soil Science 76:24.

Yaalon, D.H. 1989. Forerunners and founders of pedology as a science. Soil Science 147:225-226.
Amundson, R., and D.H. Yaalon. 1995. E.W. Hilgard and John Wesley Powell: Efforts for a joint agricultural and geological survey. Soil Science Society of America Journal 59(1):4-13.

Yaalon, D.H., and S. M. Berkowicz (eds). 1997. History of soil science - international perspectives. Catena Verlag, Reiskirchen, Germany.

Yaalon, D.H. 1997. History of soil science in context: international perspective. In: History of soil science - international perspectives. D.H. Yaalon and S. Berkowicz, eds. Catena Verlag, Reiskirchen, Germany.

Yaalon, D.H. 1998. Soil care attitudes and strategies through human history. Proceedings of the 16th World Congress of Soil Science, Montpellier, France. Vol. 2, p. 807-819.

Yaalon, D.H. 1999. On Mediterranean soil conferences: A brief history. Bulgarian Journal of Agricultural Science 6:7-8.

Yaalon, D.H. 1999. On the history and interrelationship of soil and geological mapping. Georgian State University 70th Anniversary Festschrift, Tbilisi, Georgia. p. 68-72.

Yaalon, D.H. 2000. Soil care attitudes and strategies of land use through human history. Sartoniana 13:147-159.

Yaalon, D.H., and R.W. Arnold. 2000. Attitudes toward soil and their societal relevance: then and now. Soil Science 165(1):5-12.

Yaalon, D.H. 2002. On the Dukochaev legacy. Newsletter of the Commission on the History, Philosophy, and Sociology of Soil Science of the IUSS 10:10-12.

Yaalon, D.H. 2003. Historical developments in soil classification. INHIGEO Newsletter. p. 18-21.

Yaalon, D.H. 2003. Classification: historical developments. Encyclopedia of Soil Science 1(1):1-3.

Yaalon, D.H. 2004. V.A. Kovda - meetings with a great and unique man. Newsletter of the Commission on the History, Philosophy, and Sociology of Soil Science of the IUSS 11:4-9.

\section{References}

Brevik, E.C., 2011. Historical highlights from 75 years of the Soil Science Society of America. Soil Surv. Horiz. 52 (3), 66-76.

Gabriels, D., 2000. Laudatio (for Sarton Chair of History of Science, Ghent University) Dan H. Yaalon. Sartonia 13, 143-145 (Available at http://archive.is/xddA5. (accessed 9 Feb 2014)).

IUSS, 1982. Bulletin 61. Available at http://www.iuss.org/index.php?option =com_ content\&view $=$ article\&id $=8 \&$ Itemid $=10$.

Richter, D.deB.,Yaalon, D.H., 2012. "The changing model of soil” revisited. Soil Sci. Soc. Am. J. 76 (3), 766-778.

Warkentin, B.P., 2006. A special acknowledgement and appreciation to Dan Yaalon. In: Warkentin, B.P. (Ed.), Footprints in the Soil. Elsevier, Amsterdam, p. xvii.

Yaalon, D.H., and S. M. Berkowicz (eds). 1997. History of soil science - international perspectives. Catena Verlag, Reiskirchen, Germany.

Yaalon, D.H., 2012. A Passion for Science and Zion: The Yaalon Story. Maor Wallach Press, Jerusalem, Israel.

Daniel de B Richter Nicholas School of the Environment, Duke University, Durham NC 27708, USA

Edward R. Landa Department of Environmental Science and Technology, University of Maryland, College Park, MD 20742, USA

Eric Brevik Department of Natural Science, Dickinson State University, Dickinson, ND 58601, USA

Simon Berkowicz Hebrew University of Jerusalem, Institute of Earth Sciences, Edmond J. Safra Campus, Givat Ram, Jerusalem 91904, Israel 